\title{
Preferensi Wisatawan Domestik Dalam Memilih Produk Wisata Gastronomi Di Kuta Bali
}

\author{
Komang Renaldi Artha Wijaya ${ }^{*}$, Hanugerah Kristiono Liesteandre², I Gede Gian Saputra ${ }^{3}$ \\ 1,2,3Program Studi Manajemen Kepariwisataan, Politeknik Pariwisata Bali \\ Jl. DharmawangsaKampial, Nusa Dua Bali, Telp: (0361) 773537 \\ 1*renaldikmg@gmail.com, 2andrehanoo@gmail.com, 39ian.stpnb@gmail.com \\ ${ }^{*}$ Corresponding author
}

\begin{abstract}
The purpose of this research is to analyze the preferences of domestic tourists in choosing gastronomic tourist products in Kuta. This study used online survey activities by means of sampling, namely purposive sampling and large population sample formulas. The sample in this study amounted to 200 respondents who had done culinary tourism activities in Kuta. The data is analyzed using conjoin analysis techniques. The results showed that respondents who were domestic tourists turned out when doing culinary activities in Kuta tended to like neat restaurants, good food, get cooking learning activities, and prices of Rp.10,000 Rp.30,000. In addition, it can also be known that the store atmosphere attribute is the most considered attribute by domestic tourists in choosing gastronomic travel products, followed by quality, price, activity, and the last is a service that is less considered.
\end{abstract}

Keywords: preferences, domestic tourist, Kuta destinations, conjoint analysis

\begin{abstract}
Abstrak
Tujuan peneltian ini adalah untuk menganalisis preferensi wisatawan domestik dalam memilih produk wisata gastronomi di Kuta. Penelitian ini menggunakan kegiatan survei secara online dengan cara penentuan sampel yakni purposive sampling dan rumus sampel populasi besar. Adapun sampel dalam penelitian ini berjumlah 200 responden yang pernah melakukan aktivitas wisata kuliner di Kuta. Data dianalisis menggunakan teknik analisis konjoin. Adapun hasil penelitian menunjukkan bahwa responden yang merupakan wisatawan domestik ternyata ketika melakukan aktivitas kuliner di Kuta cenderung menyukai restoran yang rapi, makanan yang enak, mendapatkan aktivitas belajar memasak, dan harga Rp.10.000 - Rp.30.000. Selain itu dapat diketahui juga bahwa atribut store atmosphere merupakan atribut yang paling dipertimbangkan oleh wisatawan domestik dalam memilih produk wisata gastronomi, kemudian diikuti oleh quality, price, activity, serta yang terakhir adalah service yang kurang menjadi pertimbangan.
\end{abstract}

Kata Kunci: preferensi, wisatawan domestik, kecamatan Kuta, analisis conjoint 


\section{PENDAHULUAN}

Sekretaris umum UNWTO, Taleb Rifai dalam Global Report on Food Tourism, AM Reports: Vol. 4 menyatakan bahwa bagi miliyaran wisatawan di dunia, pengalaman adalah tujuan dari melakukan perjalanan wisata baik dengan mengunjungi destinasi yang telah dikunjungi dengan mencoba hal-hal baru, maupun dengan mengunjungi destinasi lain yang belum pernah dikunjungi sebelumnya. Salah satu pengalaman wisata yang dikatakan menjadi sentral dari pengalaman wisatawan yaitu wisata kuliner atau yang dikenal dengan istilah gastronomy. Global Report on Food Tourism (2017) menjelaskan bahwa motivasi wisatawan untuk melakukan perjalanan ke tempat kuliner atau wisata makanan, (food tours) mencapai 63\%, serta minat wisatawan untuk mempelajari makanan setempat melalui praktik langsung (cookery workshops) tercatat 62\%. Menurut Hall dan Shraples (2003) sebagaimana yang dirangkum oleh Organisasi Pariwisata Dunia PBB (UNWTO), wisata gastronomi adalah sebuah perjalanan yang berhubungan dengan makanan ke suatu daerah dengan tujuan rekreasi. (UNWTO, Global Report on Shopping Tourism, (2016) juga menempatkan wisata belanja sebagai bagian penting dari komponen destinasi pariwisata. Global Report on Shopping Tourism mengindikasikan bahwa belanja merupakan komponen pengeluaran terbesar kedua (22\%) setelah pengeluaran atas hotel (46\%). Komponen pengeluaran untuk belanja tersebut masih di atas pengeluaran untuk makanan (foods) yang dimana mencapai 16\%.

Berdasarkan angka tahun 2018, Badan Pusat Statistik Indonesia mencatat perjalanan wisatawan dalam negeri mencapai 303,4 juta kali. Selama itu wisatawan dalam negeri tercatat mengeluarkan pengeluaran Rp 291,02 triliun. Presiden Joko Widodo dalam Rapat Terbatas (Ratas) Tatanan Normal Baru di Sektor Pariwisata yang Produktif dan Aman Covid-19 melalui konferensi virtual dari Istana Merdeka Jakarta menyatakan saat ini pariwasata Indonesia lebih difokuskan terhadap wisatawan domestik. Melihat fenomena dan rencana tersebut Kementerian Pariwisata dan Ekonomi Kreatif Indonesia mulai lebih serius melirik potensi pasar ini. Deputi Pengembangan Wisata Budaya Bidang Wisata Kuliner dan Belanja dalam bukunya yang berjudul "Pedoman Pengembangan Wisata Kuliner" menyatakan bahwa produk wisata kuliner harus berbasis pada keunggulan lokal pada masing - masing destinasi.

Bali yang dipilih sebagai destinasi kuliner tentu saja berdasarkan berbagai faktor yang mendukung adanya hal tersebut, seperti budaya, aneka ragam makanan khas, dan restoran atau rumah makan yang memadai dalam menunjang kebutuhan wisatawan. Saat ini jumlah restoran di Bali sudah terbilang cukup memadai untuk menunjang kebutuhan wisatawan akan makanan dan minuman, menurut data Badan Pusat Statistik Provinsi Bali tahun 2021 menyatakan bahwa jumlah restoran yang terdaftar mencapai 3233 unit, dengan jumlah restoran tertinggi berada pada Kabupaten Badung dengan jumlah 666 unit dan paling banyak berada pada Kecamatan Kuta yaitu 374 unit. Kriteria pemilihan restoran dan yang mempengaruhi kecenderungan ketika melakukan wisata kuliner oleh gastro-tourists juga tergantung pada suasana restoran, kualitas makanan serta kualitas layanan, harga, dan aktivitas, (Jacobsen \& Haukeland, 2002; Taar, 2014; Lee et all., 2015; Hendriyani, 2018; Nikola \& Dunja, 2020). Kecenderungan untuk memilih sesuatu yang lebih disukai daripada yang lain disebut dengan preferensi. Menurut (Kotler \& Keller 2009; Chen, et all. 2016; Adiguna, dkk. 2020) preferensi merupakan kesukaan konsumen dari berbagai pilihan produk atau jasa. Pilihan yang diambil tersebut dianggap merupakan prioritas, atau memiliki penilaian yang bagus.

Penelitian mengenai preferensi konsumen terhadap suatu produk telah dilakukan sebelumnya, pada beberapa penelitian dan perusahaan yang berbeda. Hal ini mengindikasikan bahwa preferensi konsumen merupakan hal yang penting dalam pemasaran karena berhubungan erat dengan keberhasilan perusahaan untuk mencapai tujuannya, yaitu keputusan pembelian yang dilakukan oleh konsumen atas dasar preferensi konsumen. Dengan mendalami preferensi wisatawan domestik dalam memilih 
produk wisata gastronomi maka dapat dijadikan sebagai pertimbangan untuk melakukan posisioning, merancang strategi differensiasi, mengetahui apa saja yang menjadi faktor kecenderungan wisatawan domestik dalam memilih produk wisata gastronomi, dan khususnya yang berhubungan dengan strategi memenangkan pasar yang dimana dalam hal ini segmen yang dimaksud adalah wisatawan yang melakukan aktivitas wisata kuliner di Kuta, Bali, Selain itu untuk mendukung upaya dari Presiden Joko Widodo bersama Kementerian Pariwisata dan Ekonomi Kreatif Indonesia dalam meningkatkan jumlah kunjungan wisatawan domestik, memulihkan sektor pariwisata dan

\section{METODE PENELITIAN}

Objek penelitian dari penelitian ini adalah wisatawan domestik dalam memilih produk wisata gastronomi di Kecamatan Kuta. Lokasi penelitian ini adalah Kecamatan Kuta. Sumber data yang di gunakan dalam penelitian ini adalah sumber data primer dan sumber data sekunder. Responden penelitian ini yaitu wisatawan domestik yang pernah melakukan wisata kuliner di Kecamatan Kuta sebanyak 200 responden. Teknik penentuan sampel yang digunakan dalam penelitian ini adalah purposive sampling yang dimana pengambilan sampel data diambil berdasarkan pada pertimbangan subjektif oleh peneliti dengan dasar pertimbangan sampel memiliki pengetahuan cukup tentang populasi, tepat dalam penentuan persyaratan dan menguasai permasalahan pada penelitian yang dilakukan (Mahadewi, 2018), dalam hal ini syarat yang dimaksud adalah wisatawan domestik yang pernah melakukan aktivitas wisata kuliner di Kecamatan Kuta. Penelitian ini menggunakan analisis konjoin karena terdapat pengolahan data menggunakan angkaangka. Hasil dari analisis konjoin pada penelitian ini adalah faktor yang menjadi prioritas utama bagi wisatawan domestik dalam memilih produk wisata gastronomi di Kecamatan Kuta. Menurut Malhotra (2017) analisis konjoin memiliki beberapa tujuan dalam merumuskan strategi pemasaran, antara lain untuk menunjukkan atribut mana yang paling penting dalam mempengaruhi pilihan konsumen dan menunjukkan nilai utilitas tertinggi sehingga mengetahui kombinasi atau komposisi atribut apa yang paling disukai oleh konsumen.

Dalam penelitian ini akan dilihat atribut lain dari sebuah restoran yang juga dapat mempengaruhi preferensi wisatawan domestik dalam memilih produk wisata gastronomi di Kuta. Penelitian ini menggunakan lima atribut dengan menggunakan 4 sumber referensi sebagai dasar menentukan atribut dan masing - masing atribut memiliki taraf, dimana resp onden akan memilih salah satu dari taraf yang ada tersebut sebagai taraf yang paling diminati, yang terdiri dari atribut (1) Store Atmosphere, (2) Quality, (3) Service, (4) Price, (5) Activity (mengacu pada hasil penemuan yang sama dari Jacobsen \& Haukeland, 2002; Taar, 2014; Lee et all., 2015; Hendriyani, 2018; Nikola \& Dunja, 2020)

Setelah mengetahui atribut dan taraf, tahap selanjutnya adalah dengan merancang kombinasi taraf dan atribut atau yang disebut dengan stimuli dengan pendekatan full profile yang menggambarkan profil atribut secara lengkap. Jumlah stimuli yang lengkap akan semakin baik, namun menurut Aaker et. All (2003) dalam Wahab (2011) jika jumlah stimuli terlalu banyak akan menimbulkan kesulitan bagi responden untuk menilai setiap profil stimuli yang ditanyakan hingga menyebabkan responden akan mengacuhkan variasi stimuli yang kurang penting serta membutuhkan waktu yang lama untuk menjawabnya. Oleh karena itu jumlah stimuli dikurangi dengan menggunakan perintah design orthogonal pada SPSS v.20. Sehingga dalam penelitian ini stimuli yang dihasilkan dan digunakan adalah 16 jumlah kartu stimuli. 


\section{HASIL DAN PEMBAHASAN}

\subsection{Deskripsi Data}

Kondisi exsistensi gastronomi saat kini kian meningkat dan semakin diminati oleh wisatawan, Global Report on Food Tourism oleh UNWTO (2017) menjelaskan bahwa motivasi wisatawan untuk melakukan perjalanan ke tempat kuliner atau wisata makanan, (food tours) mencapai 63\%, serta minat wisatawan untuk mempelajari makanan setempat melalui praktik langsung (cookery workshops) tercatat 62\%. Hal ini menjadikan sebuah potensi pasar atau peluang yang sangat menguntungkan. Dengan strategi yang tepat tentu saja dapat lebih mudah mengait pasar ini, menurut (Jacobsen \& Haukeland, 2002; Taar, 2014; Lee et all., 2015; Hendriyani, 2018; Nikola \& Dunja, 2020) kriteria pemilihan restoran dan yang mempengaruhi kecenderungan ketika melakukan wisata kuliner oleh gastro-tourists juga tergantung pada suasana restoran, kualitas makanan serta kualitas layanan, harga, dan aktivitas.

Saat ini Indonesia sudah memiliki destinasi yang dipilih sebagai destinasi kuliner untuk menyambut potensi pasar ini dimana destinasi-destinasi yang dipilih adalah Joglosemar, Bandung dan Bali. Alasan Bali dipilih sebagai destinasi kuliner karena memiliki aneka makanan khas daerah yang beraneka ragam, beragam budaya, dan juga restoran dan rumah makan yang sudah memadai untuk menunjang kebutuhan wisatawan, dimana Kuta adalah lokasi yang paling banyak memiliki restoran dan rumah makan. Dengan menganalisis dan mengetahui yang menjadi preferensi gastro-tourists dalam memilih produk wisata gastronomi di Kuta maka dapat mengetahui atribut mana yang menjadi prioritas atau yang paling disukai oleh wisatawan, selain mengetahui hal tersebut, menganalisis preferensi juga dapat mengetahui kombinasi atribut yang disukai oleh wisatawan dan dapat membantu pemangku kepentingan pariwisata dalam mengembangkan produk dan juga evaluasi produknya sesuai dengan apa yang diinginkan oleh wisatawan, sehingga hal ini dapat menarik wisatawan dan meningkatkan jumlah penjualan di Kuta

\subsection{Pembahasan}

Dalam penelitian ini hasil dari uji validitas dan reliabilitas menggunakan analisis conjoint yang dapat dilakukan dengan melihat nilai dari korelasi Pearson's R dan Kendall's Tau berdasarkan pada hasil pengolahan data kuesioner. Hasil dari uji validitas dan reliabilitas dapat dilihat pada tabel 1.

Tabel 1: Uji Validitas dan Reliabilitas

[Sumber: Data Penelitian, 2021]

\begin{tabular}{ccc}
\hline Nilai & Value & Sig. \\
\hline Pearson's R & .792 & .000 \\
Kendall's tau & .567 & .001 \\
\hline
\end{tabular}

Berdasarkan tabel 1 diatas, terlihat bahwa nilai korelasi Pearson's R dan Kendall's Tau untuk wisatawan domestik menghasilkan nilai yang kuat karena berada di atas nilai 0,5 yaitu 0,792 untuk nilai Pearson's $\mathrm{R}$ 0,562. Nilai signifikansi wisatawan domestik menghasilkan nilai signifikansi yang kuat karena berada di bawah nilai 0,05 dengan nilai Pearson's R 0,000 dan Kendall's Tau sebesar 0,001. Dari hasil predictive accuracy dan uji signifikansi menyatakan terdapat hubungan yang signifikan antara preferensi estimasi (hasil konjoin) dan preferensi aktual wisatawan domestik dalam memilih produk wisata gastronomi di Kecamatan Kuta. Selain uji predictive accuracy dan uji signifikansi, Hasil 
pengolahan data kuesioner dengan analisis conjoint menunjukkan tingkat kepentingan atribut dan juga nilai utilitas yang dijabarkan sebagai berikut:

1. Tingkat kepentingan atribut adalah urutan dari atribut yang paling dipertimbangkan hingga atribut yang kurang dipertimbangkan atau kurang penting menurut wisatawan. Adapun tingkat kepentingan atribut dapat dilihat pada tabel 2 .

Tabel 2: Tingkat Kepentingan Atribut

[Sumber: Data Penelitian, 2021]

\begin{tabular}{clc}
\hline No. & \multicolumn{1}{c}{ Atribut } & Value \\
\hline 1 & Store Atmosphere & 32.498 \\
2 & Quality & 28.898 \\
3 & Price & 15.220 \\
4 & Activity & 12.724 \\
5 & Service & 10.661 \\
\hline
\end{tabular}

Berdasarkan tabel 2, dapat dilihat bahwa atribut atmosfir (32.498) merupakan atribut yang paling dipertimbangakan, diikuti oleh kualitas (28.898), harga (15.220), aktivitas (12.724) dan pelayanan (10.661).

2. Analisis utilitas tiap atribut akan menunjukkan nilai dari setiap atribut yang diberikan kepada responden, nilai tersebut akan menghasilkan preferensi dari wisatawan secara keseluruhan. Preferensi yang dihasilkan dapat membantu pemangku kepentingan pariwisata dalam membuat bauran pemasaran yang lebih spesifik. Berdasarkan hasil analisis, nilai utilitas level tiap atribut dapat dilihat pada gambar 1.

\begin{tabular}{|l|l|c|}
\hline \multicolumn{1}{|c|}{ Atribut } & \multicolumn{1}{|c|}{ Taraf/Level } & Utility Estimate \\
\hline \multirow{4}{*}{ Store Atmosphere } & Restoran yang unik &,- 220 \\
\cline { 2 - 3 } & Restoran yang rapi &, 472 \\
\cline { 2 - 3 } & Restoran autentik &,- 252 \\
\hline \multirow{4}{*}{ Quality } & Makanan segar &, 036 \\
\cline { 2 - 3 } & Makanan sehat &,- 328 \\
\cline { 2 - 3 } & Makanan enak &, 292 \\
\hline \multirow{2}{*}{ Price } & Rp.10.000-Rp.30.000 &, 321 \\
\cline { 2 - 3 } & $>$ Rp.30.000 &,- 321 \\
\hline \multirow{2}{*}{ Activity } & Belajar memasak &, 044 \\
\cline { 2 - 3 } & Belajar sejarah &,- 044 \\
\hline \multirow{2}{*}{ Service } & Staff yang ramah &, 137 \\
\cline { 2 - 3 } & Staff yang sopan &,- 137 \\
\hline
\end{tabular}

Berdasarkan level atau taraf dengan nilai-nilai utilitas terbesar pada setiap atribut pada gambar 1, maka wisatawan domestik lebih menyukai kombinasi level atribut yakni restoran yang rapi $(0,472)$, makanan yang enak $(0,292)$, lebih suka belajar memasak (0,137), memilih harga dengan kategori Rp.10.000 - Rp.30.000 (0,321), dan cenderung untuk mempertimbangkan pelayanan yang ramah $(0,044)$.

\section{3 Implikasi Manajerial}

Eksistensi wisata gastronomi yang kian meningkat tiap tahunnya, membuat semakin menjamurnya kehadiran restoran atau rumah makan di Kecamatan Kuta. Terkait dengan berbagai temuan yang terungkap dalam penelitian ini, dapat digunakan sebagai bahan pertimbangan dalam menyusun strategi untuk memanfaatkan peluang semaksimal mungkin dan diharapkan membantu stakeholders pariwisata untuk melihat bagaimana perilaku konsumen dalam memilih produk wisata gastronomi, sesuai dengan pernyataan 
Swarbrooke dan Horner (2007) dalam Agustina (2018), kunci pemasaran yang baik untuk mengembangkan promosi dan produk adalah menganalisis perilaku wisatawan.

Hasil penelitian ini juga dapat digunakan sebagai evaluasi, sehingga dapat diketahui berbagai kelebihan serta kekurangan diri agar dapat dilakukan perbaikan dan pengembangan usaha, sesuai dengan hasil temuan yang menyatakan bahwa atribut atmosfir (suasana) lebih dipertimbangkan oleh wisatawan domestik dimana restoran yang rapi lebih disukai wisatawan dalam memilih produk wisata gastronomi di Kecamatan Kuta, Gernot Bohme (2019) dalam (Online Encyclopedia Philosophy of Nature, 2021) juga menekankan bahwa atmosphere dapat digambarkan sebagai ruang yang menentukan suasana hati atau sebaliknya, dimana ketika atmosphere yang di inginkan oleh wisatawan dapat terpenuhi maka dapat menimbulkan suasana hati yang positif sehingga memungkinkan wisatawan rela untuk relative lebih lama berada di tempat tersebut.

Selain faktor suasana, beberapa atribut juga harus diperhatikan dalam menarik perhatian wisatawan seperti kualitas makanan, harga, aktivitas dan pelayanan yang didapatkan, menurut Jacobsen, Haukeland (2002), Taar, (2014), Lee et all., (2015), Hendriyani (2018) Nikola dan Dunja (2020), faktor - faktor tersebut merupakan yang menjadi pengaruh mengapa wisatawan ingin melakukan wisata kuliner. Sehingga dari 5 atribut yang digunakan dalam penelitian ini nantinya dapat membantu stakeholders pariwisata dan Dinas Pariwisata Badung dalam merumuskan strategi yang tepat dalam pengembangan dan evaluasi produk wisata gastronomi di Kecamatan Kuta untuk kedepannya.

\section{KESIMPULAN}

Hasil dari penilaian atau tanggapan dari wisatawan domestik dalam pembahasan merupakan hal yang penting untuk Dinas Pariwisata Badung dan pemangku pariwisata di Kecamatan Kuta dalam menyikapi keinginan maupun kebutuhan wisatawan domestik dalam memilih produk wisata gastronomi, sehingga nantinya untuk pengembangan maupun evaluasi produk wisata gastronomi yang ada saat ini dapat dilakukan dengan tepat dan sesuai dengan apa yang di inginkan oleh wisatawan domestik. Berdasarkan analisis yang telah diuraikan dalam pembahasan, diperoleh hasil bahwa signifikansi Pearson's $R=0,000<0,05$ dan Nilai uji signifikansi Kendall's Tau=0,001 $<0,05$. Hal ini menunjukkan terdapat hubungan yang signifikan antara preferensi estimasi (hasil konjoin) dan preferensi aktual wisatawan domestik dalam memilih produk wisata gastronomi. Store Atmosphere merupakan atribut yang paling dipertimbangkan oleh wisatawan domestik pada saat memilih produk wisata gastronomi dengan nilai tertinggi yaitu $(32,498)$. Wisatawan domestik lebih menyukai kombinasi level atribut pada saat memilih produk wisata gastronomi, dengan kriteria restoran yang rapi dengan nilai $(0,472)$, makanan yang enak $(0,292)$, lebih suka belajar memasak $(0,137)$, memilih harga dengan kategori Rp.10.000-Rp.30.000 (0,321), dan memilih untuk mempertimbangkan pelayanan yang ramah $(0,044)$.

\section{DAFTAR PUSTAKA}

Adiguna, dkk. (2020). Preferensi Wisatawan Terhadap Destinasi Kampung Wisata Tabek Indah Resort Di Provinsi Lampung Dengan Teknik Analisis Conjoint. Jurnal: $e$ Proceeding of Engineering, 7(1). 1996

Agustina, N. K. W. (2018). Analisis Preferensi dan Pola Millennial Wisatawan Ke Bali. Jurnal Kepariwisataan: Edisi Khusus, 17(3), 3-4.

Nikola \& Dunja. (2020). Image of Local Cuisine as Part of a Rural Tourism Offer. Gastronomy for Tourism Development. Amanda, Digioia. Western Balkan: Emerald Publishing Limited. ISBN: 978-1-78973-756-1 
Komang Renaldi Artha Wijaya, Hanugerah Kristiono Liesteandre, I Gede Giam Saputra

Chen, et all. 2016. Travel Companios and Activity Preferences of natre-based tourists. Tourism Review, 71, hlm. 45-56 (https://doi.org/10.1108/TR-06-2015-0024)

Global Reports of A.M. UNWTO Vol. 4. 2019. Global Report on Food Tourism (https://urbact.eu/sites/default/files/import/Projects/Gastronomic_Cities/outpu ts_media/Food_tourism.pdf., Diakses 8 April 2021).

Guzel, Berrin \& Apaydin. (2016). Gastronomy Tourism: Motivations and Destinations. Adnan Menderes University Turkey.

Hall, C. M., Sharples, L., Mitchell, R., Macionis, N., \& Cambourne, B. (Eds.). (2003). Food tourism around the world: Development, management and markets. London: Routledge.

Hendriyani, Massenga \& Budiani. (2018). Persepsi Pelanggan Terhadap Kualitas Pelayanan dan Peranan Lingkungan Fisik Pada Restoran di Kota Denpasar-Bali. Jurnal Kepariwisataan Edisi Spesial, 17(3), 10

Kotler, P., \& Keller. (2007). Manajemen Pemasaran. Edisi 12, Jilid 1 dan 2. Jakarta: Pearson Education, Inc.

Mahadewi. (2018). Metodologi Penelitian Pariwisata, Usaha Perjalanan dan Hospitaliti. Depok: Rajawali Pers.

Malhotra, N. K. Daniel, N. David, F.B. (2017). Riset Pemasaran, Pendekatan Terapan edisi ke-5. New York: Pearson.

Taar, J. (2014). The Best Cullinary Experience. Factors That Create Extraordinary Eating Episode. In Elsevier, ed 2nd World Conferences on Design, Arts and Education DAE-2013., 2014

UNWTO. (2016). Global Report on Shopping Tourism. Madrid: World Tourism Organization.

UNWTO. (2017). Global Report on Food Tourism. Madrid: World Tourism Organization.

Wahab. (2011). Preferensi Mahasiswa Pada Atribut Perguruan Tinggi Melalui Analisis Konjoin. STIE Perbanas: Surabaya. 